children undergoing paediatric orthopaedic surgery; she discusses the age when patients, parents, and health professionals thought that children could-decide for themselves whether they wanted surgery that was not life saving. The children themselves set the highest threshold age for self determination at 14 years; the parents put it slightly lower at 13.9 years; and, remarkably, the health professionals chose the lowest figure, $10 \cdot 3$ years. ${ }^{1}$

While the age of informed consent remains contentious, an attempt should be made fully to explain the procedures and potential outcomes to the child, as stated by the European charter, even if the child is too young to be fully competent. After all, it is the child who will have to live with the outcome of the decision. One of the many themes running through Alderson's book is the dismay and anger expressed by children who felt cheated by the explanations, or lack of them, from parents and clinicians. Children who are legally too young to give consent to treatment must still be treated as individuals whose rights as members of society are not solely dependent on the legal definition of the day. Before accepting any consent the clinician responsible must be sure that both child and parents understand, to the best of their capacity, what is entailed-so enabling them to make a collective, considered decision. The doctor should be able to show that the views of the child were taken into account and write notes to that effect in the child's health records.

In all but the most life threatening circumstances it amounts to an abuse of a child's rights as a member of society to disregard a refusal to consent to treatment if the child seems to have made a fully informed and considered decision. This is especially true in the 1990s-for with the classic family unit having so often disintegrated the child may have a more stable and balanced viewpoint than either parent.

J P H SHIELD Research fellow

JD BAUM

Professor of child health

Institute of Child Health,

University of Bristol, Bristol BS2 8BJ

1 Alderson P. Children's consent to surgery. Buckingham: Open University Press, 1993:9.

2 [1986] AC 112.

3 Re W [1992] 3 WLR 758.

4 Devereux JA, Jones DPH, Dickenson DL. Can children withhold consent to treatment? BMf 1993;307:1459-61.

5 Alderson P. European charter of children's rights. Bulletin of Medical Ethics 1993:13-5.

6 The Children Act 1989. London: HMSO, 1989.

\title{
Autosomal dominant polycystic kidney disease
}

\section{The discovery of a second locus may improve our understanding of cyst formation}

When the $B M \mathcal{F}$ last published an editorial on adult autosomal dominant polycystic kidney disease ${ }^{1}$ there was no chromosomal assignment for the disorder. Two have since been recognised. The first, designated $\mathrm{PKD}-1,{ }^{2}$ has been localised to a narrow region of about half a million base pairs on the short arm of chromosome 16 , but the specific gene has not yet been discovered. A second locus was postulated in $1988,{ }^{3}$ and in the past few months two groups have independently confirmed that a second locus exists on chromosome $4 \mathrm{q} 13$ q23. ${ }^{45}$ What proportion of cases that this new locus accounts for and whether other loci exist are unknown.

The discovery of this second locus will improve the accuracy of presymptomatic testing and may be of prognostic significance. The disorder associated with the PKD-1 locus seems to have a more aggressive clinical course with earlier onset, more rapid progression to renal failure and hypertension, and earlier age of death than that associated with the second locus. ${ }^{6}$ Cardiovascular deaths are more common in patients with autosomal dominant polycystic kidney disease than in the general population. ${ }^{7}$ They are also commoner in patients with polycystic disease undergoing dialysis than in patients without polycystic disease undergoing dialysis. ${ }^{8}$

The identification of the second locus may improve our understanding of the underlying mechanism of cyst formation. Renal cystic change may result from many stimuli and is present in several different inherited renal disorders. In this context the recent discovery of a gene responsible for tuberous sclerosis close to the PKD-1 locus on chromosome 16 is interesting. ${ }^{9}$ As renal cysts are part of the clinical spectrum of tuberous sclerosis, advances in this disease may throw light on the pathogenesis of cystic development of polycystic kidney disease.

Several chemical toxins have been incriminated in the development of cysts in mice that are morphologically indistinguishable from those of the CPK mouse, an animal model for recessive polycystic kidney disease. Abnormal fluid accumulation associated with mislocation of the sodium-potassium ATPase pump has also been implicated. ${ }^{10}$ Currently, the most likely mechanism is an abnormal growth factor or receptor that leads to the proliferation of the renal tubular cells, and several observations support this hypothesis. Firstly, in vitro cultures of polycystic kidney epithelium show increased cell division." Secondly, left ventricular mass, which strongly predicts premature cardiovascular death, is significantly increased in asymptomatic subjects with autosomal dominant polycystic kidney disease before the onset of hypertension or renal dysfunction..$^{12}$ Increased or abnormal cellular proliferation may be responsible for this. Thirdly, the regression of cystic change within a polycystic kidney after transplantation into a non-polycystic host suggests that a circulating factor may affect the cystic change. ${ }^{14}$ Finally, the location of the second locus contains several candidate genes that regulate growth. According to Kimberling et al the endothelin 1 receptor gene may be one such candidate gene as it is expressed in the appropriate renal tissue and is located in the correct region of chromosome. ${ }^{45}$

Early diagnosis of adult autosomal dominant polycystic kidney disease improves the diagnosis and management of complications. ${ }^{15}$ Along with the previously mentioned cardiac abnormalities, this strengthens the case for considering intervention studies. For example, low protein or low sodium diets reduce cyst size in one strain of rats (Han:SPRD-CY) with autosomal dominant inherited cystic kidneys. Any intervention studies would clearly have to weigh benefit against the necessity for earlier diagnosis using genetic markers, before cysts form. The evidence for and increased recognition of potentially treatable early abnormalities in asymptomatic subjects with polycystic 
kidney disease suggest that such studies should now be seriously considered.

A K SAGGAR-MALIK

Blood Pressure Unit Williams fellow of the University of London

S JEFFERY

Senior lecturer in medical genetics

MA PATTON

Reader in medical genetics

Department of Medical Genetics,

St George's Medical School,

London SW 17 ORF

1 Curtis JR. Polycystic disease of the kidneys. BMF 1979;i:291-2.

2 Reeders S, Breuning MH, Davis KE, Nicholls RD, Jarman AP, Higgs DR, et al. A highly polymorphic DNA marker linked to adult polycystic kidney disease on chromosome 16. Nature 1985;317:542-4.

3 Kimberling WJ, Fain PR, Kenyon JB, Goldgar D, Suiansky E, Gabow PA. Linkage heterogeneity of autosomal dominant polycystic kidney disease. N Engl F Med 1988;319:913-8.

4 Peters DJM, Spruit L, Saris J, Ravine D, Sandkuijl LA, Fossdal R, et al. Chromosome 4 localisation of a second gene for autosomal dominant polycystic kidney disease. Nature Genetics 1993;5:359-62.
5 Kimberling WJ, Kumar S, Gabow PA, Kenyon JB, Connolloy CJ, Somlo S. Autosomal dominant polycystic kidney disease: localisation of the second gene to chromosome 4q13-q23. Genomic 1993;18:467-72.

6 Ravine D, Walker RG, Gibson RN, Forrest SM, Richards RT, Friend K, et al. Phenotype and genotype heterogeneity in autosomal dominant polycystic kidney disease. Lancet 1992;340:
$1330-3$.

7 Iglesias CG, Torres VE, Offord KP, Holley KE, Beard M, Kurland LT. Epidemiology of adult polycystic kidney disease, Olmsted County, Minnesota: 1935-1980. Am $\mathcal{f}$ Kidney Dis 1983;11(6): $630-9$.

8 Fassbinder W, Brunner FP, Brynger $\mathrm{H}$. Combined report on regular dialysis and transplantation in Europe. Heidelberg: Springer, 1989

European Chromosome 16 Tuberose Sclerosis Consortium. Identification and characterization of the tuberose sclerosis gene on chromosome 16. Cell 1993;75:1305-15.

10 Wilson PD, Sherwood AC, Palla K, Du J, Watson R, Norman JT. Reversed polarity of $\mathrm{Na}+\mathrm{K}+$ ATPase; mislocation to apical plasma membranes in human polycystic kidney disease epithelia. ATPase; mislocation to apical

11 Wilson PD, Hreniuk D, Gabow PA. Abnormal extracellular matrix and excessive growth of human Wilson PD, Hreniuk D, Gabow PA. Abnormal extracellular matrix and
adult polycystic kidney disease epithelia. $₹$ Cell Physiol 1992;150:360-9.

12 Saggar-Malik AK, Missouris CG, Gill J, Markandu ND, Singer DRJ, Johnston D, et al. Unexplained increase in left ventricular mass in normotensive patients with autosomal dominan polycystic kidney disease. $f$ Hypertens 1993;11(10):1150-1.

13 Zeier M, Geberth S, Schmidt K, Mandelbaum A, Ritz E. Elevated blood pressure profile and lef ventricular mass in children and young adults with autosomal polycystic kidney disease. f Am Soc Nephrol 1993;3:1451-7.

14 Siegal B. The polycystic kidney donor. Transplantation 1992;54:(6):1131.

15 Ravine D, Walker RG, Gibson RN, Sheffield LJ, Kincaid-Smith P, Danks D. Treatable complications in undiagnosed cases of autosomal dominant polycystic kidney disease. Lancet 1991:337:127-9.

\title{
The case for the community geriatrician
}

\author{
Could bridge the gap between the community and hospital
}

Geriatric medicine has developed from being a specialty that concentrated mainly on caring for chronically sick patients in long stay wards to one that deals with one third of all adult medical admissions. Inpatient services are often backed up by day hospitals bridging the gap between hospital and the community.

Many changes are underway. Between 1978-9 and 1992-3 the average length of stay in wards for older people fell from 77.5 days to 27 days. At the same time the number of people aged 85 and over who live in residential and nursing homes doubled. The introduction of social security support in 1983 for people in these homes (both voluntary and private) was responsible for the shift of many older people out of hospitals and into care homes.

The implementation of Caring For People in April 1993 also dramatically changed the organisation of care for frail and disabled older people by shifting the budget for domiciliary and residential care from the Department of Social Security to local authorities.' Local authorities are now responsible for people seeking public support in private and voluntary homes, assessing individual need, designing care arrangements, and securing the delivery of care within available resources.

The success of community care depends on collaboration between health and social services to ensure that people with complex needs receive the right balance of health and social care. Sadly, the health needs of these patients are often forgotten in this complicated recipe. The Department of Health in its Hospital Discharge Workbook emphasises the importance of close multidisciplinary working when patients are transferred from hospital back to the community. ${ }^{2}$

General practitioners are responsible for the health care of the $95 \%$ of older people who live in the community and, as care shifts from the secondary to the primary sector, are being asked to manage an increasingly sick, old, and disabled population (traditionally the responsibility of consultant geriatricians). They have had to take on this extra work with no increase in resources and little support.

General practitioners also have to support and advise staff in care homes and carry out comprehensive checks on patients over 75 as part of their contract. Anecdotal evidence suggests that older people with reversible medical problems are experiencing delays in referral to specialist care and are not having their problems treated adequately. Evidence from the Department of Health on how Caring for People was implemented suggests that general practitioners and primary health care teams had a limited input into the assessment procedures in the five local authorities that were examined. ${ }^{3}$

Can the needs for care of vulnerable older people be better served? The British Geriatrics Society has recently offered a solution-the creation of a subspecialty of community geriatric medicine. ${ }^{4}$ The consultant in this subspecialty could work mainly in the community but would have access to and responsibility for acute beds in district general hospitals as well as for rehabilitation and continuing care beds. Trusts would have to grant them equal status to their hospital colleagues if they were to set up an integrated service straddling both hospital and community. The society suggests that one of their key functions would be to liaise with primary health care teams; they would also provide a medical service to social services departments. All community geriatricians would have to be accredited in geriatric medicine.

Such an arrangement preserves the autonomy of general practitioners but enables consultants to take a lead in developing community care for older people. Rather than working in isolation, community geriatricians could form part of locality based teams. Community teams have been successfully developed for elderly patients with mental illness; ; they should now be evaluated in older people with physical health problems. The creation of another subspecialty to bridge the gap between hospital and the community could break barriers not only between consultants and general practitioners but also between health and social services.

\section{JACKIE MORRIS}

Royal Free Hospital Trust,

Consultant physician in medicine of old age

London NW3 2 QG

1 Caring for People. Community care in the next decade and beyond. London: HMSO, 1989. (Cm849.)

2 Department of Health. Hospital Discharge Workbook. A manual on hospital discharge practice. London: DoH, 1994.

3 Department of Health. Monitoring and Development. First impressions April-September 1993. London DoH, 1994.

4 British Geriatrics Society. Community geriatrician. London: BGS, 1994

5 Coles RJ, Von Abendorff R, Herzberg JL. The impact of a new community mental health team on an inner city psychogeriatric service. International Fournal of Geriatric Psychiatry 1991;6:31-9. 